\title{
Analisis Kinerja Pegawai Pada Kantor Camat
}

\section{Analysis of Employee Performance at the Head Office}

\author{
Muhammad Reza Syahputra1), Isnaini'2) \& Adam ${ }^{1) *}$
}

\author{
1)Program Magister Ilmu Administrasi Publik, Universitas Medan Area, Indonesia \\ 2) Fakultas Hukum, Universitas Medan Area, Indonesia
}

Diterima: 03 Juni 2021; Direview: 03 Juni 2021; Disetujui: 29 November 2021

\begin{abstract}
Abstrak
Berdasarkan hasil analisis Laporan Akuntabilitas Kinerja Instansi Pemerintah (LAKIP) Kecamatan Medan Timur 2020 menunjukkan kinerja pegawai yang masih rendah, dan terdapat masalah yang perlu dibenahi terkait disiplin kerja aparatur. Metode Penelitian yang digunakan dalam penelitian ini adalah deskriptif dengan analisis kualitatif. Pengumpulan data di peroleh dari wawancara, dokumentasi, dan observasi. Dengan hasil penelitian bahwa kualitas kerja pegawai Kantor Camat Medan Timur Kota Medan masih rendah dalam hal pengurusan surat-surat dan prosedurnya juga masih berbelit-belit dan lambat serta tidak transparan dalam hal biaya. Kuantitas kerja pegawai Kantor Camat Medan Timur Kota Medan sudah cukup baik. Disiplin kerja pegawai Kantor Camat Medan Timur Kota Medan belum berjalan sesuai dengan yang diharapkan masyarakat. Pegawai yang ada di Kantor Camat Medan Timur Kota Medan memiliki inisiatif yang baik dalam melaksanakan tugas-tugasnya. Serta tanggung jawab pegawai terhadap seluruh aspek yang berhubungan dengan tugas-tugas yang dilaksanakan oleh pegawai Kantor Camat Medan Timur Kota Medan sudah cukup baik.

Kata Kunci: Analisis; Kantor Camat Medan Timur Kota Medan; Kinerja Pegawai
\end{abstract}

\begin{abstract}
Based on the results of the analysis of the 2020 East Medan District Government Agency Performance Accountability Report, it shows that employee performance is still low, and there are problems that need to be addressed related to apparatus work discipline. The research method used in this research is descriptive with qualitative analysis. Data collection is obtained from interviews, documentation, and observations. The results showed that the work quality of the employees of the East Medan District Head Office, Medan City was still low in terms of handling documents and procedures were still convoluted and slow and not transparent in terms of costs. The work quantity of the employees of the Medan Timur Sub-district Office in Medan City is quite good. The work discipline of the employees of the East Medan Sub-district Office, Medan City, has not yet been implemented as expected by the community. Employees at the Medan Timur Sub-district Office in Medan City have good initiatives in carrying out their duties. As well as the employee's responsibility for all aspects related to the tasks carried out by the employees of the East Medan District Head Office, Medan City is quite good.
\end{abstract}

Keywords: Analysis; East Medan District Head Office; Medan City; Employee Performance.

How to Cite: Muhammad Reza Syahputra, Isnaini \& Adam. (2022). Analisis Kinerja Pegawai Pada Kantor Camat. PERSPEKTIF, 11 (1): 61-68

\begin{tabular}{lr}
\hline *Corresponding author: & ISSN 2085-0328 (Print) \\
E-mail: adam@staff.uma.ac.id & ISSN 2541-5913 (online)
\end{tabular}




\section{PENDAHULUAN}

Kinerja pegawai dikatakan meningkat dan semakin berkualitas apabila individu yang ada dalam organisasi berhasil mencapai standar kerja yang telah ditetapkan oleh organisasi (As'ad, 2005) dan dijadikan sebagai acuan penentu keberhasilan individu dalam bekerja. Kinerja pegawai bisa digunakan sebagai suatu tolak ukur suatu organisasi. pengukuran keberhasilan maupun kegagalan instansi pemerintah dalam menjalankan tugas pokok dan fungsinya sulit dilakukan secara obyektif. (Hasibuan, 2002) menyatakan bahwa kinerja adalah suatu hasil kerja yang dicapai seseorang dalam melaksanakan tugas-tugas yang dibebankan kepadanya yang berdasarkan atas kecakapan, pengalaman dan kesungguhan serta waktu.

Menurut (Uno, 2007) kinerja pegawai yang dimaksud adalah hasil kerja pegawai yang terefleksi dalam cara merencanakan dan melaksanakan segala tugas yang intensitasnya dilandasi oleh etos kerja, serta profesional pegawai dalam proses pekerjaan (Nasution \& Sinaga, 2014; Siregar, 2011). Kinerja dapat dipengaruhi oleh beberapa faktor, salah satunya yang dikatakan oleh Robbins dan Judge (2006: 184) bahwa kepuasan kerja yang dirasakan oleh karyawan merupakan faktor yang dapat mempengaruhi kinerja karyawan. Sehingga dapat dikatakan apabila seorang karyawan merasakan kepuasan kerja maka akan berpengaruh positif pula terhadap peningkatan kinerja karyawan tersebut.

Kecamatan Medan Timur adalah salah satu instansi pemerintahan. Camat adalah perangkat pemerintahan wilayah kecamatan yang menyelenggarakan pelaksanaan tugas pemerintahan diwilayah Kecamatan Medan Timur Kota Medan yang bekerja untuk masyarakat dimana sudah seharusnya memberikan pelayanan yang terbaik bagi masyarakat. Untuk mendapatkan pelayanan yang baik, pegawai Kantor Camat Medan Timur Kota Medan harus dapat bekerja seefektif mungkin dalam menjalankan tugasnya. Hasil observasi di Tahun 2019 pada Kantor Camat Medan Timur Kota Medan menunjukkan kinerja pegawai yang masih rendah. Dengan indikasi ketidakdisiplinan pegawai pada jam masuk dan pulang kantor serta kecenderungan untuk menunda pekerjaan.

Berdasarkan hasil analisis Laporan Akuntabilitas Kinerja Instansi Pemerintah
(LAKIP) Kecamatan Medan Timur 2020 bahwa masih ada masalah yang perlu dibenahi terkait disiplin kerja aparatur Pemerintah setempat, dimana dalam memberikan pelayanan terhadap masyarakat mengenai urusan, seperti surat menyurat dan lain sebagainya dapat dikatakan belum optimal. Disiplin kerja dalam instansi mempunyai tujuan untuk mengarahkan tingkah laku para pegawai dengan sejumlah peraturan yang menunjang pencapaian tujuan instansi.

Kantor Camat Medan Timur juga melaksanakan pengukuran kinerja terhadap Indikator Kinerja Utama (IKU) maupun indikator kinerja sasaran strategis organisasi yang telah ditetapkan dalam dokumen Perjanjian Kinerja Kecamatan Medan Timur Tahun 2019. Instruksi Presiden No. 7 Tahun 1999 tentang Akuntanbilitas Kinerja Instansi Pemerintah, mewajibkan setiap instansi untuk mempertanggungjawabkan pelaksanaan tugas pokok dan fungsinya serta kewenangan pengelolaan sumber daya dengan didasarkan suatu perencanaan sasaran strategi yang ditetapkan oleh masing-masing instansi. Media yang digunakan untuk pelaporan akuntabilitas tersebut adalah Laporan Akuntabilitas Kinerja Instansi Pemerintah (LAKIP) yang merupakan hasil dari suatu proses Sistem Akuntabilitas Kinerja Instansi Pemerintah (SAKIP). Namun demikian, mekanisme akuntabilitas sebagaimana diatur oleh sejumlah peraturan tersebut belum memenuhi kriteria akuntabilitas publik. Mekanisme akuntabilitas yang diatur dalam LAKIP hanya ditujukan secara internal kepada atasan saja serta hanya mengukur sejauh mana target yang sudah ditetapkan telah tercapai dalam rangka pelaksanaan misi organisasi.

Masalah-masalah seperti kualitas pegawai yang masih dinilai kurang untuk menunjang penyelesaian tugas dan pekerjaan pada masing-masing di bidang tenaga kerja. Karena sistem pengukuran kinerja yang merupakan elemen pokok dari laporan akuntabilitas instansi pemerintah akan mengubah paradigma pengukuran keberhasilan. Melalui pengukuran kinerja, keberhasilan suatu instansi pemerintah akan lebih dilihat dari kemampuan instansi tersebut, berdasarkan sumber daya yang dikelolanya sesuai dengan rencana yang telah disusun. Sementara itu sistem penilaian kinerja dengan menggunakan LAKIP (Laporan Akuntabilitas 
Kinerja Instansi Pemerintah) juga belum mampu mengukur kinerja pegawai secara tepat. Berdasarkan pengamatan diatas maka dilihat terjadinya inefisiensi kinerja sehingga terjadi kekurangdisiplinan di kalangan pegawai (Pulungan., 2011)

Urusan pemerintahan umum ini diselenggarakan oleh setiap kepala wilayah pada setiap tingkatan sebagai wakil pemerintah pusat di daerah dalam rangka melaksanakan asas dekonsentrasi. Tugas umum pemerintahan yang diselenggarakan oleh Camat tidak dimaksudkan sebagai pengganti urusan pemerintahan umum, karena Camat bukan lagi sebagai kepala wilayah. Selain itu, intinya juga berbeda.

Kinerja adalah penampilan hasil karya personel baik kuantitas maupun kualitas dalam suatu organisasi. Kinerja dapat merupakan penampilan individu maupun kelompok kerja personel (Ilyas, 2011). Kinerja adalah hasil kerja secara kualitas dan kuantitas yang dicapai oleh seseorang karyawan dalam melaksanakan tugasnya sesuai dengan tanggung jawab yang diberikan kepadanya. Mathis dan Jackson (2012) berpendapat bahwa: "Kinerja pada dasarnya adalah apa yang dilakukan atau tidak dilakukan karyawan. Kinerja pegawai adalah yang mempengaruhi seberapa banyak mereka memberi kontribusi kepada organisasi yang antara lain termasuk kuantitas output, kualitas output, jangka waktu output, kehadiran di tempat kerja, dan sikap kooperatif.

Untuk mengetahui seseorang mempunyai kinerja atau tidak maka dapat dilakukan melalui penilaian. Penilaian (Performance Appraisal) dapat dilakukan dengan membandingkan prestasi aktual pegawai dengan rencana kinerja yang diharapkan organisasi, penilaian kinerja memainkan peranan yang sangat penting dalam meningkatkan motivasi di tempat kerja (Siregar, 2019). Penilaian kinerja (Performance appraisal) adalah suatu proses melalui manajemen organisasi-organisasi mengevaluasi atau menilai kinerja pegawai. Kinerja ini dapat memperbaiki keputusankeputusan kepersonaliaan dan memberikan upah balik bagi pegawai dalam pelaksanaan pekerjaannya.

Suradji (2003) menyatakan bahwa: Kinerja (performance) adalah hasil kerja yang dapat dicapai seseorang atau sekelompok orang dalam suatu organisasi, sesuai dengan wewenang dan tanggung jawab masingmasing, dalam rangka mencapai tujuan organisasi bersangkutan secara legal, tidak melanggar hukum dan sesuai dengan moral maupun etika (Sudarto, 2011; (Rizal, 2011). Pendapat lain yang dikemukakan oleh Moh. Pabundu Tika (2010) bahwa "Kinerja sebagai hasil-hasil fungsi pekerjaan atau kegiatan seseorang atau kelompok dalam suatu organisasi yang dipengaruhi oleh berbagai faktor untuk mencapai tujuan organisasi dalam periode waktu tertentu".

Kinerja Pegawai mempunyai hubungan erat dengan pemberdayaan sumber daya manusia karena merupakan indikator dalam menentukan bagaimana usaha untuk mencapai tingkat produktivitas yang tinggi dalam suatu organisasi. Sehubungan dengan hal tersebut maka upaya untuk mengadakan penilaian terhadap kinerja dalam suatu organisasi merupakan hal penting. Menurut (Mangkunegara, 2010) bahwa "Kinerja Pegawai adalah hasil kerja secara kualitas dan kuantitas yang dicapai oleh seorang Pegawai dalam melaksanakan tugasnya sesuai dengan tanggung jawab yang diberikan kepadanya". (Hasibuan, 2010; Andika \& Tarigan, 2013; Muslim \& Irwan, 2014; Sinaga, Kadir, \& Mardiana, 2019) bahwa "Kinerja Pegawai adalah suatu hasil kerja yang dicapai seseorang dalam melaksanakan tugas-tugas yang dibebankan kepadanya yang didasarkan atas kecakapan, pengalaman, dan kesungguhan serta waktu".

Aspek penilaian kinerja Pegawai menurut (Mangkunegara, 2004), diantaranya adalah Kualitas Kerja, Kuantitas Kerja, Disiplin dalam bekerja, Inisiatif, Tanggung Jawab. Faktor yang mempengaruhi pencapaian kinerja adalah kemampuan (ability) dan faktor motivasi (motivation) (Simbolon, A.H., dan Walid M.S., 2015). Hal ini sesuai dengan pendapat Keith Davis yang diterjemahkan oleh (Mangkunegara, 2004), yaitu faktor kemampuan, Secara psikologis, kemampuan (ability) Pegawai terdiri dari kemampuan potensi (IQ) dan kemampuan nyata (knowledge and skill). Manuskrip ditulis dengan kerapat. Faktor motivasi Motivasi terbentuk dari sikap (attitude) seorang Pegawai dalam menghadapi situasi (situation) kerja. Motivasi merupakan kondisi yang menggerakkan diri Pegawai yang terarah untuk mencapai tujuan organisasi (tujuan kerja). 


\section{METODE PENELITIAN}

Penelitian ini menggunakan metode Deskriptif dengan teknik analisis Kualitatif dikarenakan permasalahan yang belum jelas. Proses penelitian kualitatif ini melibatkan upaya seperti mengajukan pertanyaan dan mengumpulkan data yang spesifik dari para partisipan, menganalisis data (Creswell 2010). Lokasi Penelitian ini akan dilakukan di Kecamatan Medan Timur Kota Medan.

Pengumpulan data dalam penelitian adalah menggunakan data primer dan data sekunder. Data primer merupakan data yang didapat dari hasil observasi langsung di lapangan dengan mempelajari dan mengamati keadaan fisik wilayah tersebut serta melakukan wawancara kepada berbagai narasumber seperti Camat Medan Timur Kota Medan.

\section{HASIL DAN PEMBAHASAN}

Fokus penelitian adalah bagaimana kinerja pegawai Kantor Camat Medan Timur Kota Medan. Dan dapat di lihat dari sikap dan tindakannya ketika melakukan aktivitasnya sehari-hari dalam mengerjakan pekerjaan administratif, dan aktivitasnya mengadakan pembinaan atau sosialisasi kepada masyarakat sehubungan dengan program pemerintah Kota Medan. Untuk mengetahui kinerja pegawai Kantor Camat Medan Timur Kota Medan saat ini, peneliti memilih menggunakan 5 dimensi kinerja pegawai yang dikemukakan oleh (Mangkunegara, 2004) yaitu kualitas kerja, kuantitas kerja, disiplin dalam bekerja, inisiatif dan tanggung jawab.

Kualitas kerja, Untuk mengukur dimensi ini dalam upaya mengetahui kinerja pegawai Kantor Camat Medan Timur Kota Medan dapat diukur melalui indikator sebagai berikut: ketepatan, ketelitian, keterampilan, dan keberhasilan kerja. Ketepatan, terdapat pegawai yang datang terlambat, dan ada yang pulang sebelum jam kantor usai. Terkadang sewaktu jam kantor melakukan aktivitas pribadi dan melakukan aktivitas yang tidak berhubungan dengan urusan dinas, dan sebagainya, kinerja pegawai Kantor Camat Medan Timur Kota Medan terkesan lambat dan berbelit-belit. Hal ini membuat masyarakat enggan untuk datang seperti masyarakat awam. kondisi sekarang yang didapat di daerah menunjukkan bahwa penyelenggaraan pelayanan publik masih dihadapkan pada sistem pemerintahan yang belum efektif dan efisien serta kualitas sumber daya manusia aparatur yang belum memadai. Hal ini terlihat dari masih banyaknya keluhan dari masyarakat baik secara langsung maupun tidak langsung seperti prosedur yang berbelit-belit, tidak ada kepastian dalam jangka waktu penyelesaian, biaya yang harus dikeluarkan, persyaratan yang kurang transparan, sikap petugas yang kurang responsive.

Keterangan yang diberikan oleh Bapak Andi, terlihat bahwa kurangnya responsif pegawai yang dapat dilihat ketika mengurus surat menyurat harus menunggu waktu lebih dari satu hari. Berdasarkan pendapat dari Rusydi (2017) bahwa pelayanan (service) adalah suatu usaha untuk membantu menyiapkan (mengurus) apa yang diperlukan seseorang atau orang lain, terhadap kita yang membentuk suatu keterikatan hak dan kewajiban masing-masing pihak. Namun hasil observasi dan wawancara yang di dapat ketepatan pegawai Kantor Camat Medan Timur Kota Medan, secara umum dapat dikatakan kurang baik.

Aspek ketelitian dan keterampilan adalah prakarsa yang datang dari diri pegawai untuk melaksanakan sesuatu yang berkaitan dengan tugas-tugasnya maupun bukan tanpa harus diperintah pimpinan. Berdasarkan hasil observasi, umumnya pegawai yang ada di Kantor Camat Medan Timur Kota Medan memiliki inisiatif yang baik dalam melaksanakan tugas-tugasnya. Berdasarkan pengamatan peneliti juga terlihat bahwa setiap pegawai mampu mengoperasikan setiap fasilitas yang digunakan dalam bekerja. Hasil wawancara yang dilakukan kepada bapak Sekretaris Camat Medan Timur Kota Medan dan Bapak Camat Medan Timur Kota Medan mengungkapkan belum ada masalah yang terlihat dari ketidakmampuan pegawai dalam mengoperasikan teknologi. Namun hasil penelitian yang dilakukan, diperoleh informasi pegawai Kantor Camat Medan Timur Kota Medan tidak proporsional. Dikarenakan terbatasnya ketersediaan sumber daya manusia (SDM) di Kantor Camat Medan Timur Kota Medan.

Berdasarkan hasil wawancara, bahwa profesionalisme perlu dimiliki oleh seorang pegawai. Seperti keterampilan dan ketelitian pegawai, sistem dan prosedur kerja yang efisien. Apabila keterampilan tersebut berhasil dijalankan dan diselesaikan dengan baik, maka 
kinerja sumber daya manusia dianggap berkualitas. Menurut Benardin dan Russel dalam (Priansa, 2017; Haryati, E., Suharyanto, A. Hasmayni, B. \& Siregar, F.H. 2019) menyatakan bahwa kinerja merupakan hasil yang di produksi oleh fungsi pekerjaan tertentu atau kegiatan pada pekerjaan tertentu selama periode waktu tertentu. Dalam hal ini Camat Medan Timur Kota Medan sudah berusaha untuk membuat pelatihan pegawai guna meningkatkan kinerja keterampilan dan keahlian pegawai. Namun masih menunggu hasil dari kepegawaian daerah

Dalam penelitian ini mutu pekerjaan diinterpretasikan sebagai kualitas kerja dari pegawai Kantor Camat Medan Timur Kota Medan. Pencermatan pada aspek ini dilakukan melalui hasil pelaksanaan kinerja yang dilakukan oleh para pegawai Kantor Camat Medan Timur Kota Medan. Berdasarkan hasil wawancara kepada informan, kualitas kerja yang diberikan pegawai Kantor Camat Medan Timur Kota Medan masih rendah dalam hal pengurusan surat-surat dan prosedurnya juga masih berbelit-belit dan lambat serta tidak transparan dalam hal biaya. Pegawai yang dipercayakan untuk melaksanakan suatu pekerjaan tidak berada di tempat.

Kuantitas Kerja, Menurut Dessler (2000) menyatakan bahwa kinerja merupakan prestasi kerja dengan standar yang ditentukan. Kemampuan dalam melaksanakan tugas bukan hanya dibutuhkan seorang pegawai yang profesional. Hal tersebut dapat dilihat pula dari keterampilan dan pengalaman pegawai, tentunya dalam hal ini juga ditunjang oleh kualitas sumber daya manusia yang dimilikinya. Hal tersebut sama denga pernyataan Sekretaris Camat Medan Timur Kota Medan dan Camat dengan pengalaman tersebut seorang pegawai Kantor Camat Medan Timur Kota Medan lebih mengetahui seluk beluk tentang pekerjaan yang menjadi tugas pokok dan fungsinya atau tanggungjawabnya yang telah dituangkan kedalam Sasaran Kerja Pegawai (SKP).

Pegawai Kantor Camat Medan Timur Kota Medan dalam melaksanakan tugas perlu memperhatikan sasaran yang akan dijadikan obyek termasuk kecepatan dalam memberikan layanan kepada masyarakat. Sebagai aparatur pemerintah dan sebagai abdi masyarakat harus mampu melihat gejolak perkembangan ilmu pengetahuan secara global dan menjadi panutan. Dalam mewujudkan pelaksanaan kerja Pegawai Kantor Camat yang diharapkan masyarakat perlu kiranya ditunjang dengan perangkat yang memiliki kemampuan disiplin kerja, semangat kerja yang tinggi serta kesadaran akan tugas dan tanggung jawabnya sebagai abdi Negara dan abdi masyarakat.

Hasil penelitian yang dilakukan, memperlihatkan terbatasnya ketersediaan Sumber Daya Manusia (SDM) pada Kantor Camat Medan Timur Kota Medan. Keterbatasan kualitas SDM ini berpengaruh terhadap kualitas kemampuan pelaksanaan pekerjaan. Namun pegawai Kantor Camat Medan Timur Kota Medan selalu berusaha dan berupaya untuk meningkatkan sumber daya manusia. Maka berdasarkan observasi dan wawancara yang peneliti lakukan, kuantitas kerja di Kantor Camat Medan Timur Kota Medan sudah cukup baik apabila kemampuan tersebut berhasil dijalankan dan diselesaikan dengan baik, maka individu sumber daya manusia juga dianggap berkualitas.

Disiplin dalam bekerja, Disiplin dalam bekerja adalah pegawai harus disiplin pada dirinya, tugasnya, serta mentaati peraturanperaturan yang berlaku. Dari observasi peneliti selama melakukan penelitian terlihat bahwa pegawai Kantor Camat Medan Timur Kota Medan kurang efektif dalam melaksanakan tugas sehari-hari, bahkan cenderung tidak efektif ditinjau dari aspek disiplin waktu. Hal ini terlihat dari kehadiran pegawai pada setiap hari kerja yang sangat terbatas. Hal ini berdasarkan dengan Peraturan Pemerintah (PP) No. 53 Tahun 2010 yang di tetapkan dalam rangka mewujudkan PNS yang handal, profesional, dan bermoral sebagai penyelenggara pemerintahan yang menerapkan prinsip-prinsip kepemerintahan yang baik (good governance) (Sirait, N., Warjio, W., Harahap, D., \& Kadir, A., 2019; ). Oleh karena itu PNS sebagai unsur aparatur negara dituntut untuk setia kepada Pancasila, Undang-Undang Dasar Negara Republik Indonesia Tahun 1945, Negara Kesatuan Republik Indonesia, dan Pemerintah, bersikap disiplin, jujur, adil, transparan, dan akuntabel dalam melaksanakan tugas.

Namun pada kenyataannya, disiplin pegawai Kantor Camat Medan Timur Kota Medan masih terlihat rendah di dalam disiplin waktu dan disiplin kerja pegawai yang di dapat melalui hasil wawancara dengan informan. Di 
dalam PP No. 53 Tahun 2010 tentang disiplin PNS juga di jelaskan kewajiban dan larangan PNS secara tegas dan di sebutkan jenis hukuman disiplin yang dapat di jatuhkan terhadap suatu pelanggaran disiplin (Sihombing, et al., 2020). Hal ini dimaksudkan sebagai pedoman bagi pejabat yang berwenang menghukum serta memberikan kepastian dalam menjatuhkan hukuman disiplin. Demikian juga dengan batasan kewenangan bagi pejabat yang berwenang menghukum telah ditentukan dalam Peraturan Pemerintah tersebut. Penjatuhan hukuman disiplin dimaksudkan untuk membina PNS yang telah melakukan pelanggaran, agar yang bersangkutan mempunyai sikap menyesal dan berusaha tidak mengulangi dan memperbaiki diri pada masa yang akan datang.

Berdasarkan hasil observasi dan wawancara, peneliti dapat menyimpulkan bahwa standar disiplin kerja di Kantor Camat Medan Timur Kota Medan berbeda-beda pada setiap bidang. Oleh karena itu pengawasan disiplin kerja oleh Camat Medan Timur Kota Medan harus sering dilakukan. Karena berdasarkan pengamatan peneliti pada saat melakukan observasi di lapangan, masih banyak para pegawai yang bekerja tidak maksimal. Hal ini terjadi karena kurangnya pengawasan yang dilakukan oleh pimpinan. Kurangnya disiplin pegawai menjadikan pelayanan yang diberikan kepada masyarakat tidak sesuai dengan harapan masyarakat dimana terkadang ada masyarakat yang sudah berada di Kantor Camat Medan Timur Kota Medan untuk mengurus surat namun pegawai yang berwenang belum juga tiba di kantor mengakibatkan si masyarakat harus menunggu sampai pegawai tersebut tiba di kantor.

Inisiatif, Kinerja pegawai dapat dilihat dari rasa kepedulian, keuletan dan keseriusan dalam melaksanakan tugas. Dengan kepedulian, keuletan dan keseriusan tersebut akan menunjukkan apakah pegawai tersebut mempunyai inisiatif dalam melaksanakan tugas yang menjadi tugas pokok dan fungsinya dan dengan inisiatif yang dimiliki oleh pegawai tersebut akan memberikan image masyarakat bahwa pegawai adalah pelayan dan abdi masyarakat yang siap melaksanakan tugas.

Berdasarkan hasil wawancara kepada Bapak Sekertaris Camat Medan Timur, maka di dapat bahwa dukungan kebijakan yang di sertai dengan dorongan inisiatif atau prakarsa dari pegawai Kantor Camat Medan Timur Kota Medan dalam meningkatkan kinerja akan mampu meningkatkan kinerja pegawai. Oleh karena itu tugas pokok dan fungsi yang merupakan tugas keseharian harus dilaksanakan dengan baik. Inisiatif pegawai Kantor Camat Medan Timur Kota Medan dalam meningkatkan kinerja merupakan langkah maju dalam menjunjung tinggi citra Pegawai Negeri Sipil sebagai abdi masyarakat, sehingga pegawai Kantor Camat Medan Timur Kota Medan bukan hanya menunggu perintah atau menunggu laporan, tetapi mempunyai inisiatif untuk kemajuan dalam mencapai tujuan yang telah ditetapkan dalam Sasaran Kerja Pegawai (SKP) setiap tahunnya. Hasil penelitian menunjukkan bahwa pegawai Kantor Camat Medan Timur Kota Medan kadang senantiasa berupaya untuk meningkatkan inisiatif dalam bekerja.

Berdasarkan hasil observasi dan wawancara, umumnya pegawai yang ada di Kantor Camat Medan Timur Kota Medan memiliki inisiatif yang baik dalam melaksanakan tugas-tugasnya. Sebagai contoh, jika suatu saat pegawai yang tupoksinya bertanggung jawab menangani urusan suratmenyurat tidak masuk kantor, tetapi pegawai yang lain akan bersedia membantu tugastugasnya yang berkaitan dengan yang dibutuhkan masyarakat. Dengan adanya inisiatif seperti ini maka kinerja pegawai tetap berjalan dengan baik seperti biasanya sesuai yang diharapkan masyarakat dan selalu meningkat dalam waktu ke waktu.

Tanggung Jawab, Seperti yang telah diuraikan sebelumnya, bahwa tugas dan fungsi pemerintah demikian luas dan kompleks (administrasi dalam arti luas) yaitu meliputi seluruh aspek kehidupan masyarakat. Hal ini berarti tugas pegawai juga demikian adanya. Berdasarkan hasil wawancara yang di dapat bahwa Kantor Camat Medan Timur Kota Medan telah melaksanakan evaluasi dari kinerja pegawai selama ini. Selain dengan aparat Kecamatan, peneliti juga melakukan wawancara dengan Tokoh Pemuda di Kecamatan Medan Timur yang memnyatakan bahwa pelaksanaan kinerja yang dilakukan oleh pegawai Kantor Camat Medan Timur Kota Medan selama ini sudah cukup baik meskipun masih perlu adanya pembenahan dan penyempurnaan. Berdasarkan hasil wawancara yang di dapat maka dapat diketahui 
bahwa pelaksanaan kinerja pegawai terhadap seluruh aspek yang berhubungan dengan tugas-tugas yang dilaksanakan oleh pegawai Kantor Camat Medan Timur Kota Medan sudah cukup baik meskipun masih perlu ada berbagai pembenahan yang harus dilakukan.

Berdasarkan hasil wawancara dan observasi peneliti, maka dapat diketahui bahwa tanggung jawab pegawai terhadap seluruh aspek yang berhubungan dengan tugas-tugas yang dilaksanakan oleh pegawai Kantor Camat Medan Timur Kota Medan sudah cukup baik meskipun masih perlu ada berbagai pembenahan yang harus dilakukan. Hal ini terlihat dari prioritas yang diberikan yang sesuai dengan misi dari Kantor Camat Medan Timur Kota Medan untuk menyediakan pelayanan yang tepat waktu dan bernilai baik. Serta kemudahan akses dan penggunaan teknologi dalam bekerja.

\section{Hambatan Kinerja Pegawai Kantor Camat Medan Timur Kota Medan}

Terdapat beberapa faktor yang menjadi hambatan kinerja pegawai Kantor Camat Medan Timur Kota Medan. Tidak bisa dipungkiri ada banyak hal yang bisa mempengaruhi proses pelaksanaan tersebut. Disiplin Pegawai, Pelaksanaan tugas di kantor oleh para pegawai belum menunjukkan etos kerja yang tinggi, kurang disiplin dan masih melekatnya sifat ketergantungan yang tinggi terhadap pimpinan. Dalam PP No. 53 Tahun 2010 tentang Disiplin PNS di nyatakan bahwa disiplin PNS adalah kesanggupan PNS untuk menaati kewajiban dan menghindari larangan yang ditentukan dalam peraturan perundangundangan dan/atau peraturan kedinasan yang apabila tidak ditaati atau dilanggar dijatuhi hukuman disiplin. Sementara itu dalam pelaksanaan tugas berdasarkan hasil observasi dan fakta di lapangan yang peneliti temukan adalah masih munculnya kebiasaan pegawai yang sering menunda pekerjaan, atau dengan kata lain lebih mementingkan urusan pribadi. Hal ini dapat dilihat pada jam-jam tertentu yakni pegawai tidak berada di ruang kerjanya atau berada di luar kantor dengan urusan pribadi yang tidak berkaitan dengan tugas kantor.

Kualits Pribadi, Sesuai hasil observasi peneliti di lapangan masih di temukan pegawai yang belum sepenuhnya bersikap profesional dalam menyelesaikan suatu permasalahan.
Kualitas pribadi dapat dikatakan masih kurang. Ditunjukkan dari sikap keramahtamahan pegawai yang belum bisa menunjukkan sikap baik untuk melayani masyarakat. Karena pelayanan yang ramah tamah akan mendatangkan sikap yang baik. Berdasarkan hal tersebut dapat disimpulkan bahwa kualitas pribadi pegawai menjadi hambatan kinerja pegawai dalam rangka mencapai visi organisasi. Sikap pegawai yang kurang berperan aktif dalam memberikan pemahaman kepada masyarakat mengenai alur proses pelayanan, minimnya koordinasi, pemberian petunjuk teknis mengenai pelayanan belum dilakukan secara rutin dan berkala. Selain itu pegawai Kantor Camat Medan Timur Kota Medan kurang memperhatikan kebutuhan dari pelayanan masyarakat. Berdasarkan hasil wawancara, kualitas pribadi pegawai dapat di katakan sebagai hambatan kinerja pegawai dalam pelayanan administratif di Kantor Camat Medan Timur Kota Medan.

\section{SIMPULAN}

Kualitas kerja pegawai Kantor Camat Medan Timur Kota Medan masih rendah dalam hal pengurusan surat-surat prosedurnya juga masih berbelit-belit dan lambat serta tidak transparan dalam hal biaya. Kuantitas kerja pegawai Kantor Camat Medan Timur Kota Medan sudah cukup baik apabila kemampuan tersebut berhasil dijalankan dan diselesaikan dengan baik. Disiplin kerja pegawai Kantor Camat Medan Timur Kota Medan belum berjalan sesuai dengan yang diharapkan masyarakat. Masyarakat ada yang merasa kecewa ketika pengurusan surat harus menunggu waktu yang lama, dan ketidakhadiran pegawai kantor menyebabkan ketidakpuasan masyarakat atas kinerja pegawai. Pegawai yang ada di Kantor Camat Medan Timur Kota Medan memiliki inisiatif yang baik dalam melaksanakan tugas-tugasnya. Tanggung jawab pegawai terhadap seluruh aspek yang berhubungan dengan tugas-tugas yang dilaksanakan oleh pegawai Kantor Camat Medan Timur Kota Medan sudah cukup baik meskipun masih perlu ada berbagai pembenahan yang harus dilakukan.

Pelaksanaan tugas di kantor oleh para pegawai belum menunjukkan etos kerja yang tinggi, kurang disiplin dan masih melekatnya sifat ketergantungan yang tinggi terhadap pimpinan. Munculnya kebiasaan pegawai yang sering menunda pekerjaan, atau dengan kata 
lain lebih mementingkan urusan pribadi, hal ini dapat dilihat pada jam jam tertentu pegawai tidak berada di ruang kerjanya atau berada di luar kantor dengan urusan pribadi yang tidak berkaitan dengan tugas kantor. Kualitas pribadi dapat dikatakan masih kurang, ditunjukkan dari sikap keramahtamahan pegawai yang belum bisa menunjukkan sikap baik untuk melayani masyarakat. Karena pelayanan yang ramah tamah akan mendatangkan sikap yang baik. Berdasarkan hal tersebut dapat disimpulkan bahwa kualitas pribadi pegawai menjadi hambatan kinerja pegawai dalam rangka mencapai visi organisasi.

\section{DAFTAR PUSTAKA}

Andika, M, dan Tarigan, U. (2013). Evaluasi Kinerja Pemerintah Desa Bandar Tengah Kecamatan Bandar Khalifah Kabupaten Serdang Bedagai, JPPUMA: Jurnal Ilmu Pemerintahan dan Sosial Politik UMA (Journal of Governance and Political UMA), 1 (2): 98-111

Haryati, E., Suharyanto, A. Hasmayni, B. \& Siregar, F.H. (2019). The Effect of Work Environment and Work Stress on Employee Performance at PT Aneka Gas Industri Tbk Research Article in Proceedings of the 2nd International Conference on Social Sciences and Interdisciplinary Studies (formerly ICCSSIS), ICCSIS 2019, 24-25 October 2019, Medan, North Sumatera, Indonesia

Hasibuan, M.S.P. (2002). Manajemen Sumber Daya Manusia. Jakarta: PT Bumiperkasa

Ilyas, Yaslis, 2011. Kinerja. Jakarta: Universitas Indonesia.

Instruksi Presiden Nomor 7 Tahun 1999 tentang Akuntanbilitas Kinerja Instansi Pemerintah.

Mangkunegara, A. A. Anwar Prabu. 2016. Manajemen Sumber Daya Manusia Perusahaan. Bandung: PT. Remaja Rosdakarya.

Mangkunegara, A. A. Anwar Prabu. 2017. Manajemen Sumber Daya Manusia Perusahaan. Bandung: Remaja Rosdakarya

Mangkunegara, Anwar. 2007. Manajemen Sumber Daya manusia. Bandung: Remaja Rosdakarya

Muslim, N. dan Irwan N., (2014). Kinerja Aparat Desa Dalam Penyelenggaraan Pemerintahan Di Desa Pantai Labu Pekan, JPPUMA: Jurnal Ilmu Pemerintahan dan Sosial Politik UMA (Journal of Governance and Political UMA), 2 (2): 114-124

Nasution, F.R. dan Rudi S.S., (2014). Evaluasi Kinerja Pegawai Kantor Samsat dalam Pelayanan Bea Balik Nama Kendaraan Bermotor, JPPUMA: Jurnal Ilmu Pemerintahan dan Sosial Politik
UMA (Journal of Governance and Political UMA), 2 (1): 1-17

Peraturan Pemerintah Nomor 53 Tahun 2010 tentang Disiplin Pegawai Negeri Sipil

Priansa, D. 2017. Manajemen Kinerja Kepegawaian. Bandung: CV. Pustaka Setia.

Pulungan, I., (2011), Strategi Badan Kepegawaian Daerah Kota Binjai Dalam Meningkatkan Kinerja Pegawai Negeri Sipil, Jurnal Administrasi Publik : Public Administration Journal : Public Admnistration Journal, 1 (1): 82-101

Rizal, M.F., (2011), Analisis Kinerja Aparatur Birokrasi (Studi pada Sekretariat Daerah Kabupaten Aceh Timur), Jurnal Administrasi Publik : Public Administration Journal : Public Admnistration Journal, 1 (2): 112-129

Sihombing, S., Nainggolan, E., Diafri, D., Sitompul, G., \& Anggoro, M. (2020). Pengaruh Kompetensi, Disiplin Dan Pengembangan Karier Terhadap Kinerja Karyawan PT. Asam Jawa Medan. Journal of Education, Humaniora and Social Sciences (JEHSS), 3(1), 273-280. doi:https://doi.org/10.34007/jehss.v3i1.303

Simbolon, A.H., dan Walid M.S., (2015). Evaluasi Kinerja Badan Permusyawaratan Desa dalam Penyelenggaraan Pemerintahan Desa, JPPUMA: Jurnal Ilmu Pemerintahan dan Sosial Politik UMA (Journal of Governance and Political UMA), 1 (1): 143-159.

Sinaga, A., Kadir, A., \& Mardiana, S. (2019). Peranan Motivasi Kerja Dalam Kinerja Pegawai Pada Kantor Kecamatan Tanjungbalai Utara Kota Tanjung Balai. Strukturasi: Jurnal Ilmiah Magister Administrasi Publik, 1(1), 32-42

Sirait, N., Warjio, W., Harahap, D., \& Kadir, A. (2019). Analisis Kinerja Aparatur Sipil Negara dalam hal Disiplin Kerja di Kantor Kecamatan Tanjungbalai Utara Kota Tanjungbalai. Strukturasi: Jurnal Ilmiah Magister Administrasi Publik, 1(2), 165-175

Siregar, D. (2019). Pengaruh Motivasi dan Kompensasi terhadap Kinerja Karyawan pada Perseron Terbatas Digitdata Terminal Evolusi. Journal of Education, Humaniora and Social Sciences (JEHSS). 2 (1): $74-82$

Siregar, H., (2011), Analisis Kinerja Aparatur Birokrasi (Studi pada Bagian Sekretariat Daerah Kabupaten Labuhanbatu), Jurnal Administrasi Publik : Public Administration Journal : Public Admnistration Journal, 1 (1): 51-64

Stephen P. Robbins. 2002. Perilaku Organisasi. Jakarta: PT. Prenhallindo

Sudarto, (2011), analisis kompetensi dan kinerja aparatur pada Dinas sosial dan tenaga kerja kabupaten karo, Jurnal Administrasi Publik : Public Administration Journal, 1 (1): 102111. 

Muhammad Reza Syahputra, Isnaini \& Adam. Analisis Kinerja Pegawai Pada Kantor Camat

Sirait, N., Warjio, W., Harahap, D., \& Kadir, A. (2019). Analisis Kinerja Aparatur Sipil Negara dalam hal Disiplin Kerja di Kantor Kecamatan Tanjungbalai Utara Kota Tanjungbalai. Strukturasi: Jurnal Ilmiah Magister Administrasi Publik, 1(2), 165-175 Nurmiah, N., Kusmanto, H., \& Lubis, Y. (2019). Analisis Kinerja Pemerintah Kelurahan dalam Program Pemberdayaan Kebersihan Kelurahan. Strukturasi: Jurnal Ilmiah Magister Administrasi Publik, 1(2), 176-183.

Novita, D., Kadir, A., \& Siregar, N. (2020). Analisis Kinerja Inspektorat Daerah Dalam Melakukan Fungsi Pengawasan (Studi Pada Inspektorat Kota Langsa). Strukturasi: Jurnal Ilmiah Magister Administrasi Publik, 2(2), 116-128. doi:https://doi.org/10.31289/strukturasi.v2 i2.52

Ketike, R., Harahap, R., \& Siregar, N. (2021). Analisis Kinerja Dinas Pengelolaan Keuangan Daerah Di Bidang Pendapatan Pada Kabupaten Gayo Lues. Strukturasi: Jurnal Ilmiah Magister Administrasi Publik, 3(1), 99-117. doi:https://doi.org/10.31289/strukturasi.v3 i1.726

Samsudin, M. (2021). Analisis Kinerja Pelayanan Publik tentang Sumber Daya Manusia dan Responsivitas Pegawai di Kantor Kelurahan Kecandran Kecamatan Sidomukti Kota Salatiga. Journal of Education, Humaniora and Social Sciences (JEHSS), 4(2), 1028-1034. doi:https://doi.org/10.34007/jehss.v4i2.794 